\title{
KEEFEKTIFAN MODEL PEMBELAJARAN MATEMATIKA REALISTIK DITINJAU DARI PRESTASI BELAJAR DAN KREATIVITAS SISWA SEKOLAH DASAR
}

\author{
THE EFFECTIVENESS OF THE REALISTIC MATHEMATICS LEARNING MODEL \\ IN TERMS OF ELEMENTARY SCHOOL STUDENTS' LEARNING ACHIEVEMENT \\ AND CREATIVITY
}

\author{
Budiharti, Jailani \\ Universitas PGRI Yogyakarta, Universitas Negeri Yogyakarta \\ budiharti85@yahoo.co.id, jailani@uny.ac.id
}

\begin{abstract}
Abstrak
Penelitian ini bertujuan untuk (1) mendeskripsikan keefektifan model pembelajaran matematika realistik dan cooperative learning tipe Student Team Achievement Divison (STAD) ditinjau dari prestasi belajar dan kreativitas siswa SD pada Mata Pelajaran Matematika, (2) menyelidiki perbedaan keefektifan model pembelajaran matematika realistik dan model cooperative learning tipe STAD ditinjau dari prestasi belajar dan kreativitas siswa SD. Penelitian ini berjenis eksperimen semu dengan desain Nonequivalent control group design. Terdapat dua kelas eksperimen dan satu kelas kontrol. Populasi adalah siswa MIN Tempel dengan sampel siswa kelas IVA, IVB dan IVC. Uji beda menggunakan MANOVA. Penentuan tingkat keefektifan pembelajaran menggunakan uji $t$. Hasil penelitian menunjukkan bahwa ditinjau dari prestasi belajar dan kreativitas siswa, (1) model pembelajaran matematika realistik dan model cooperative learning tipe STAD sama-sama efektif , (2) terdapat perbedaan kefektifan antara model pembelajaran matematika realistik dengan cooperative learning tipe STAD, (3) model pembelajaran matematika realistik lebih efektif daripada model cooperative learning tipe STAD.
\end{abstract}

Kata kunci: Pembelajaran Matematika Realistik, Prestasi, Kreativitas

\begin{abstract}
This study aims to: (1) describe the effectiveness of the application of the realistic mathematics learning model and cooperative learning model of the Student Team Achievement Division (STAD) type in terms of elementary school students' learning achievement and creativity in the mathematics subject, (2) investigate the difference in the effectiveness between the realistic mathematics learning model and the cooperative learning model of the STAD type in terms of elementary school students' learning achievement and creativity. This was a quasi-experimental study employing the nonequivalent control group design. The study involved two experimental classes and one control group. The research population consisted of students of MIN Tempel, Sleman. To test the difference in the effectiveness, MANOVA was employed. Then the t-test was employed to determine which method was more effective. The results of the study in terms of the students' learning achievement and creativity are as follows. (1) The realistic mathematics learning model and the cooperative learning model of the STAD type are effective. (2) There is a difference in the effectiveness between the realistic mathematics learning model and the cooperative learning model of the STAD type. (3) The realistic mathematics learning model is more effective than the cooperative learning model of the STAD type.
\end{abstract}

Keyword: Realistic Mathematic, Achievement, Creativity 


\section{Pendahuluan}

Pendidikan yang dikelola dengan tertib, teratur, efektif, dan efisien akan mampu memercepat jalannya proses pemberdayaan bangsa yang bertujuan pokok pada peningkatan kesejahteraan umum dan mencerdaskan kehidupan bangsa. Melalui pendidikan, pengembangan kualitas sumber daya manusia Indonesia dapat ditingkatkan terus menerus demi kepentingan masa depan bangsa. Pendidikan sekolah merupakan pendidikan yang dilaksanakan melalui kegiatan belajar mengajar yang berkesinambungan, sedangkan pendidikan luar sekolah adalah kegiatan belajar mengajar yang tidak harus berjenjang dan berkelanjutan, termasuk di dalamnya pendidikan dalam keluarga. Pendidikan merupakan cara yang penting untuk membentuk pribadi yang tangguh, berkualitas, berkompetensi, cerdas, kreatif, inovatif, bertanggung jawab, berpotensi diri, mampu menguasai ilmu pengetahuan dan teknologi sehingga dapat mengikuti perkembangan globalisasi yang semakin pesat.

Pendidikan juga memunyai peranan yang sangat menentukan bagi perkembangan dan perwujudan diri individu, terutama bagi pembangunan bangsa dan negara. Kemajuan suatu kebudayaan bergantung pada cara kebudayaan mengenali, menghargai, dan memanfaatkan sumber daya manusia dan hal ini berkaitan erat dengan kualitas pendidikan yang diberikan kepada anggota masyarakatnya, yaitu peserta didik.

Untuk mencapai suatu tujuan pendidikan yang diharapkan dalam proses belajar mengajar, seorang guru dituntut untuk menguasai kompetensi dengan baik dan sesuai dengan rencana serta kurikulum yang berlaku. Penguasaan kompetensi yang baik terhadap matematika berkaitan erat dengan bagaimana daya upaya komponen yang berpengaruh dalam pendidikan. Selain itu, menurut Wong (2013) keahlian dari seorang guru merupakan satu faktor yang paling penting dalam menentukan prestasi peserta didik. Oleh karena itu, peningkatan mutu pengajaran matematika harus selalu diupayakan sehingga mampu mengatasi tuntutan jaman.

Berdasarkan data hasil UASBN SD/MI di Daerah Istimewa Yogyakarta tahun 2009/ 2010, untuk SD/MI negeri rata-rata nilai pada mata pelajaran Bahasa Indonesia adalah 7,47, mata pelajaran IPA 6,97 dan mata pelajaran Matematika adalah 7,14. Sedangkan untuk SD/ MI swasta rata-rata nilai pada mata pelajaran
Bahasa Indonesia adalah 7,59, mata pelajaran IPA 7,14 dan mata pelajaran Matematika adalah 7,27. (KR Jogja, 11 Juni 2010). Dari data tersebut terlihat bahwa rata-rata nilai mata pelajaran matematika masih lebih rendah dibandingkan dengan mata pelajaran yang lain.

Kreativitas merupakan aspek penting yang perlu dikembangkan dan tidak bisa ditinggalkan, guru dan orangtua harus mengembangkan keberanian dan kreativitas (Wong, 2013). Menurut Munandar (2009, p.6) pendidikan diharapkan dapat menyediakan lingkungan yang memungkinkan bakat dan kemampuan peserta didik secara optimal sehingga dapat mewujudkan pendidikan yang berfungsi sepenuhnya, sesuai dengan kebutuhan pribadi peserta didik dan kebutuhan masyarakat. Kreativitas akan tumbuh dan berkembang dengan baik jika lingkungan keluarga, masyarakat, maupun lingkungan sekitar mendukung peserta didik mengeksplorasi kreativitasnya.

Pada saat ini pembelajaran Matematika di sekolah-sekolah masih menggunakan cara konvensional. Guru lebih memfokuskan pada penghafalan rumus untuk memecahkan masalah. Menurut Thoha (Kompas, 18 Juni 2009), untuk memecahkan masalah dalam matematika, fokus para guru lebih menekankan siswa untuk menghafal rumus daripada membantu siswa memahami konsep matematika dan mengaitkannya dengan pembentukan cara berpikir logis. Dengan adanya pembelajaran matematika yang seperti ini kreativitas siswa akan terhambat. Siswa tidak diberikan kebebasan dalam berpikir. Untuk mengajarkan suatu pelajaran pada anak didik tidak cukup dengan memberikan rumus atau hafalan, karena model pembelajaran semacam ini akan menghilangkan kesempatan anak didik untuk melatih kreativitas berpikir. Menurut Anshor (2009) dari penelitian para ahli pendidikan, anak-anak lebih banyak menerima komentar negatif (larangan, hukuman, caci-maki) dan sedikit sekali komentar positif (kesempatan, penghargaan, pujian) dari orang yang lebih tua dalam kehidupannya, akibatnya banyak siswa yang enggan berperan aktif dalam kegiatan pembelajaran. Kegiatan yang menuntut penampilan, bertanya jawab, presentasi, diskusi, atau berpidato juga tidak disukai oleh siswa, jiwa mereka diliputi perasaan takut salah, malu, dan rendah diri. Oleh karena itu dperlukan adanya model pembelajaran yang menyenangkan yang dapat memberikan kesempatan pada anak didik untuk melatih 
kreativitas berpikir dan berperan aktif dalam kegiatan pembelajaran.

Menurut Marpaung (2008, p.2) pembelajaran matematika yang berlangsung di sekolah pada umumnya masih didominasi oleh paradigma mengajar, yaitu: (1) pembelajaran berpusat pada guru (guru aktif menransfer pengetahuan pada pikiran siswa), (2) matematika disampaikan pada siswa sebagai produk yang sudah jadi, bukan sebagai proses, dan (3) murid menerima pengetahuan secara pasif. Dari uraian tersebut terlihat bahwa kreativitas siswa kurang dikembangakan.

Lebih lanjut diungkapkan bahwa proses pendidikan yang ideal adalah proses pendidikan yang dikemas dengan memerhatikan berbagai aspek. Proses pengajaran di sekolah lebih mementingkan target pencapaian kurikulum daripada penghayatan isi kurikulum secara imajinatif dan kreatif. Dalam pembelajaran, aspek kreativitas sering ditinggalkan karena lebih menekankan pada penguasaan materi. Sempitnya waktu dan beban materi merupakan alasan utama para guru untuk meninggalkan kreativitas. Siswa kurang mendapatkan kesempatan untuk mengambil peran lebih aktif dan kreatif dalam suasana yang menyenangkan.

Oleh karena itu pembelajaran matematika di kelas seharusnya ditekankan pada keterkaitan antara konsep-konsep matematika dengan pengalaman anak sehari-hari. Selain itu, perlu penerapkan kembali konsep matematika yang telah dimiliki anak pada kehidupan seharihari atau pada bidang lain sangat penting dilakukan. Salah satu pembelajaran matematika yang berorientasi pada matematisasi pengalaman sehari-hari (mathematize of everyday experience) dan menerapkan matematika dalam kehidupan sehari-hari adalah Pembelajaran Matematika Realistik. Pembelajaran Matematika Realistik pertama kali dikembangkan dan dilaksanakan di Belanda dan dipandang sangat berhasil untuk mengembangkan pengertian siswa.

Menurut Hadi (2005, p.80), dalam menyelesaikan masalah kontekstual pada pembelajaran matematika dengan model pembelajaran matematika realistik siswa diberi kesempatan menggunakan cara-cara mereka sendiri. Dengan demikian kepada siswa dibiasakan untuk bebas berpikir dan berani berpendapat. Hal ini sesuai dengan model pembelajaran yang diharapkan dapat memberikan kesempatan pada peserta didik untuk melatih kreativitas berpikir.
Selain model pembelajaran matematika realistik, salah satu model pembelajaran yang dapat dipilih oleh guru dalam melaksanakan pembelajaran matematika di sekolah dasar yaitu dengan menggunakan model pembelajaran kooperatif (cooperative learning). Pembelajaran kooperatif dirancang untuk meningkatkan kerja sama akademik antarsiswa, membentuk hubungan positif, mengembangkan rasa percaya diri, serta meningkatkan kemampuan akademik melalui aktivitas kelompok. Dalam pembelajaran kooperatif terdapat saling ketergantungan positif di antara siswa untuk mencapai tujuan pembelajaran. Setiap siswa memunyai kesempatan yang sama untuk sukses. Aktivitas belajar berpusat pada siswa dalam bentuk diskusi, mengerjakan tugas bersama, saling membantu, dan saling mendukung dalam memecahkan masalah. Model pembelajaran kooperatif dipandang sebagai proses pembelajaran yang aktif karena siswa berbagi tanggung jawab dengan siswa lainnya termasuk dengan guru untuk menciptakan keadaan belajar dan berusaha bersama memenuhi tugas pengembangan keterampilan serta penguasaan kompetensi yang sedang dipelajari. Siswa akan belajar lebih banyak melalui proses pembentukan dan penciptaan, melalui kerja dengan tim, dan melalui berbagi pengetahuan sesama siswa. Hal ini sesuai dengan model pembelajaran yang diharapkan dapat memberikan kesempatan pada peserta didik untuk melatih kreativitas berpikir.

\section{Metode}

\section{Jenis Penelitian}

Penelitian ini dilakukan dengan metode quasi eksperimen menggunakan pretest-postest nonequivalent control group design, yang bertujuan membandingkan tiga perlakuan yang berbeda kepada subjek penelitian. Metode eksperimen dipilih karena peneliti merancang pembelajaran matematika yang belum diketahui keunggulannya atau keberhasilannya dibandingkan dengan pembelajaran secara langsung. Peneliti merancang pembelajaran matematika dengan model pembelajaran realistik dan model cooperative learning tipe STAD, kemudian melakukan percobaan untuk mengetahui keefektifannya ditinjau kreativitas siswa dan prestasi belajar siswa. 


\section{Waktu dan Tempat Penelitian}

Penelitian ini dilaksanakan di kelas IV MIN Tempel Sleman. Waktu penelitian dilaksanakan pada bulan November-Desember 2012.

Populasi dan Sampel Penelitian

Populasi dalam penelitian ini adalah seluruh siswa MIN Tempel Sleman pada semester Gasal 2012/2013. Banyaknya siswa MIN Tempel pada saat dilaksanakan penelitian adalah sebanyak 575 siswa. Untuk menentukan kelas yang akan digunakan untuk penelitian dipilih secara random dengan cara pengundian. Pengundian dilakukan pada kelas I sampai dengan kelas VI, yang akhirnya terpilih kelas IV. Kelas yang terpilih adalah kelas IVA, IVB, dan IVC yang masing masing beranggotakan 27 siswa, 26 siswa, dan 28 siswa. Selanjutnya dipilih secara random untuk memeroleh kelas yang akan dikenai model pembelajaran. Dari hasil pengundian diperoleh kelas IVC dikenai model pembelajaran matematika realistik, kelas IVA dikenai model cooperative learning tipe STAD, dan kelas IVB dengan model pembelajaran langsung. Rancangan penelitian menggunakan desain pretest-posttest nonequivalent control group design (Wirsma, 1986, p.143).

Tabel 1. Desain Penelitian

\begin{tabular}{cccc}
\hline $\mathrm{KE}_{1}$ & $O_{1}$ & $X_{1}$ & $O_{2}$ \\
$\mathrm{KE}_{2}$ & $O_{1}$ & $X_{2}$ & $O_{2}$ \\
$\mathrm{KK}$ & $O_{1}$ & $X_{0}$ & $O_{2}$
\end{tabular}

Keterangan :

$\mathrm{KE}_{1}$ : Kelompok Eksperimen 1

$\mathrm{KE}_{2}$ : Kelompok Eksperimen 2

KK : Kelompok Kontrol

$\mathrm{O}_{1}:$ Pretest

$\mathrm{O}_{2}$ : Posttest

$\mathrm{X}_{2}$ : Pembelajaran matematika dengan model pembelajaran matematika realistik

$\mathrm{X}_{1}$ : Pembelajaran matematika dengan model cooperative learning tipe STAD

$\mathrm{X}_{0}$ : Pembelajaran matematika dengan model pembelajaran langsung

Prosedur

Penelitian dilakukan melalui 8 tahap, yaitu (1) pembuatan instrument, (2) prasurvei dan perizinan, (3) pertemuan koordinasi, (4) pretest, (5) perlakuan di kelas eksperimen, (6) observasi, (7) posttest, dan (8) analisis data.
Data, Instrumen, dan Teknik Pengumpulan Data

Variabel independen dalam penelitian ini adalah penerapan model pembelajaran matematika dengan pembelajaran matematika realistik, penerapan model pembelajaran matematika dengan cooperative learning tipe $\mathrm{STAD}$, penerapan model pembelajaran matematika dengan pembelajaran langsung. Variabel dependen penelitian ini adalah prestasi belajar matematika dan kreativitas siswa. Instrumen penelitian yang digunakan dalam penelitian ini tes prestasi belajar, tes kreativitas, angket, dan lembar observasi. Tes prestasi digunakan untuk mengukur prestasi belajar siswa pada pretest dan posttest. Materi tes berdasarkan materi pelajaran pada bidang studi matematika bagi siswa kelas IV semester 1 sesuai dengan standar isi pada Kurikulum Tingkat Satuan Pendidikan (KTSP). Tes kreativitas digunakan untuk mengukur kreativitas siswa, yang kemudian diolah bersamasama dengan hasil angket. Angket diberikan kepada siswa yang bertujuan untuk mengetahui kreativitas siswa. Lembar observasi digunakan untuk mengamati mengamati kreativitas siswa selama proses belajar berlangsung.

\section{Teknik Analisis Data}

Teknik analisis yang digunakan adalah dengan menggunakan statistik deskriptif dan inferensial. Deskripsi data dilakukan melalui analisis deskriptif. Data yang dideskripsikan merupakan data yang diperoleh dari pengukuran pada variabel-variabel penelitian yaitu prestasi dan kreativitas pada pre-test maupun post-test. Untuk menguji perbedaan keefektifan ketiga model pembelajaran ditinjau dari prestasi dan kretivitas siswa, digunakan pengujian Multivariate Analysis of Variance (MANOVA). MANOVA merupakan perluasan dari ANOVA, yaitu jika pada ANOVA hanya dapat menguji perbedaan keefektifan untuk satu variabel dependen maka MANOVA dapat menguji perbedaan keefektifan untuk dua variabel dependen atau lebih (Hair, et.al, 2006, p.388). Sebelum dilakukan pengujian dengan MANOVA ada beberapa asumsi yang harus dipenuhi terlebih dahulu, setelah asumsi dipenuhi barulah dapat dilakukan pengujian MANOVA.

\section{Uji Kesahihan Asumsi}

Uji kesahihan asumsi dilakukan dengan uji normalitas dan uji homogenitas. Uji normalitas bertujuan untuk mengetahui apakah data 
berdistribusi normal atau tidak. Uji normalitas dilakukan terhadap data yang diperoleh baik sebelum maupun setelah perlakuan. Data tersebut melibuti data tes kreativitas dan prestasi belajar matematika siswa pada ketiga kelas. Pada uji normalitas ini digunakan uji Kolmogorov-Smirnov. Taraf signifikansi yang digunakan adalah $\alpha=5 \%$. Jika nilai signifikansi yang dihasilkan lebih dari 0,05 maka populasi berdistribusi normal. Sebaliknya jika nilai signifikansi yang dihasilkan kurang dari 0,05 data tidak berdistribusi normal. Uji normalitas ini dilakukan dengan menggunakan SPSS 17.0 for windows. Keluaran dari hasil analisis secara ringkas dapat dilihat pada Tabel 2 berikut.

Tabel 2. Rangkuman Uji Normalitas Pre-test dan Post-test pada Kelas Model PMR, STAD dan Langsung

\begin{tabular}{lllll}
\hline No & Instrumen & Kelas & Sig. & Kriteria \\
\hline \multirow{4}{*}{1} & Pretest & KE1 & 0,722 & Normal \\
& Kreativitas & KE2 & 0,933 & Normal \\
& & KK & 0,829 & Normal \\
\multirow{2}{*}{2} & Pretest & KE1 & 0,503 & Normal \\
& Prestasi & KE2 & 0,870 & Normal \\
& & KK & 0,306 & Normal \\
\multirow{2}{*}{3} & Posttest & KE1 & 0,694 & Normal \\
& Kreativitas & KE2 & 0,826 & Normal \\
& & KK & 0,259 & Normal \\
& & KE1 & 0,265 & Normal \\
4 & Posttest & KE2 & 0,282 & Normal \\
& Prestasi & KK & 0,192 & Normal \\
\hline
\end{tabular}

Berdasarkan Tabel 2, terlihat bahwa nilai signifikansi untuk semua hasil pretest dan posttest prestasi belajar dan kreativitas pada ketiga kelas adalah lebih dari 0,05. Oleh karena itu, dapat disimpulakn bahwa variabel penelitian berdistribusi normal.

Uji homogenitas kovarian digunakan untuk mengetahui varians kovarians kedua populasi adalah sama atau tidak. Uji homogenitas dilakukan terhadap skor pretest dan posttest. Untuk mengetahui tingkat homogenitas matriks varians-kovarians dilakukan melalui uji homogenitas Box-M (Hair, Black, Babin, Anderson \& Tathan, 2006, p.409). Pengujian dilakuakn dengan menggunakan bantuan SPSS 17 for windows. Sedangkan untuk mengetahui homogenitas varians dua kelompok dilakukan melalui homogenitas Levene's dengan bantuan SPSS 17 for windows.

Pengujian homogenitas untuk uji multivariat menggunakan Box's $M$ test dilakukan dengan fasilitas SPSS 17 for windows. Kriteria pengujian ditetapkan jika angka signifikansi atau probabilitas yang dihasilkan secara bersama-sama lebih dari 0,05 , maka matriks varians-kovarians populasi adalah sama. Dari hasil perhitungan diperoleh nilai $\mathrm{F}$ adalah 0,909 dan peluang galat adalah 0,487 . Terlihat bahwa nilai peluang galat lebih besar dari taraf signifikansi $5 \%$ atau 0,05 , maka dapat disimpulkan bahwa variansi kedua populasi adalah sama atau homogen.

Berdasarkan uji normalitas dan homogenitas di atas diperoleh bahwa data awal berdistribusi normal dan variansi ketiga populasi adalah homogen.

Uji Hipotesis

\section{Analisis Keefektifan Model Pembelajaran}

Analisis keefektifan dilakukan untuk menunjukkan tingkat pencapaian tujuan pembelajaran yang difokuskan pada pengukuran variabel-variabel pembelajaran yang telah didefinisikan. Nilai kriteria ketuntasan minimal (KKM) untuk prestasi adalah 70. Analisis keefektifan model pembelajaran untuk prestasi belajar dengan menggunakan uji $t$ satu sampel. Analisis keefektifan mpdel pembelajaran ditinjau dari kreativitas adalah dengan menggunakan uji $t$ berpasangan, untuk melihat apakah ada perbedaan (peningkatan) kreativitas antara sebelum dan sesudah model pembelajaran dilakukan.

\section{Uji Multivariat Kondisi Awal}

Uji multivariat kondisi awal dilakukan dengan MANOVA yang bertujuan untuk melihat ada atau tidaknya perbedaan prestasi dan kreativitas pada kedua kelas sebelum perlakuan. Jika hasil analisis menunjukkan tidak adanya perbedaan maka dapat dilakukan uji lanjut, namun jika terdapat perbedaan maka selanjutnya dilakukan MANCOVA. Pengujian hipotesisnya sebagai berikut.

$\mathrm{H}_{0}:\left(\begin{array}{l}\mu_{1 p} \\ \mu_{1 k}\end{array}\right)=\left(\begin{array}{l}\mu_{2 p} \\ \mu_{2 k}\end{array}\right)=\left(\begin{array}{l}\mu_{0 p} \\ \mu_{0 k}\end{array}\right)$

$\mathrm{H}_{1}$ : Tidak semua vektor rata-rata ketiga populasi sama dengan, 
$\mu_{1 p}$ : mean dari prestasi belajar dengan menggunakan model pembelajaran matematika realistik

$\mu_{1 k}$ : mean dari kreativitas siswa dengan menggunakan model pembelajaran matematika realistik

$\mu_{2 p}$ : mean dari prestasi belajar dengan menggunakan model cooperative learning tipe STAD

$\mu_{2 k}$ : mean dari kreativitas siswa dengan menggunakan model cooperative learning tipe STAD

$\mu_{0 p}$ : mean dari prestasi belajar dengan menggunakan model pembelajaran langsung

$\mu_{0 k}$ : mean dari kreativitas siswa dengan menggunakan model pembelajaran langsung

Statistik uji yang digunakan dalam MANOVA adalah Pillai's Trace, Wilk's Lambda, Hotteling's Trace, dan Roy's Largest Root. Kriteria penerimaan dan penolakan hipotesis adalah $\mathrm{H}_{0}$ diterima jika nilai signifikansi lebih dari 0,05 pada taraf signifikansi 5\%. Uji hipotesis dengan menggunakan bantuan SPSS 17 for windows.

Tabel 3. Rangkuman Uji Multivariat dengan MANOVA pada Data Awal

\begin{tabular}{lcrr}
\hline \multicolumn{1}{c}{ Kategori } & Nilai & Nilai F & Nilai Sig \\
\hline Pillai's Trace & 0,022 & 0,425 & 0,791 \\
Wilks' Lambda & 0,978 & 0,422 & 0,793 \\
Hotelling's Trace & 0,022 & 0,418 & 0,795 \\
Roy's Largest Root & 0,022 & 0,850 & 0,431 \\
\hline
\end{tabular}

Dari hasil perhitungan tersebut nilai peluang galat (Sig.) untuk Pillai's Trace, Wilks Lambda, Hotteling's Trace dan Roy's Largest Root pada Grup adalah lebih dari dari 0,05 ma$\mathrm{ka}_{0}$ diterima. Jadi dapat disimpulkan bahwa tidak terdapat perbedaan prestasi belajar dan kreativitas pada ketiga kelas sebelum dilakukan eksperimen.

Uji Multivariat Kondisi Akhir

Pengujian hipotesis tahap kedua dengan hipotesis sebagai berikut.

$\mathrm{H}_{0}:\left(\begin{array}{l}\mu_{1 p} \\ \mu_{1 k}\end{array}\right)=\left(\begin{array}{l}\mu_{2 p} \\ \mu_{2 k}\end{array}\right)=\left(\begin{array}{l}\mu_{0 p} \\ \mu_{0 k}\end{array}\right)$

$\mathrm{H}_{1}$ : Tidak semua vektor rata-rata ketiga populasi sama

Cara perhitungannya sama dengan perhitungan uji multivariat pada kondisi awal.

\section{Uji Univariat}

Jika uji hipotesis tahap kedua menyatakan bahwa terdapat perbedaan keefektifan pembelajaran antara model pembelajaran matematika realistik, model cooperative learning tipe STAD, dan model pembelajaran langsung ditinjau dari prestasi dan kreativitas siswa, dan data berdistribusi normal dan homogen, maka dilanjutkan uji lanjut yaitu statistik uji $\mathrm{t}$ untuk menentukan variabel yang berkonstribusi terhadap keseluruhan. Rumus yang digunakan dalam menguji hipotesis tersebut menggunakan statistik uji t dengan rumus

$t=\frac{\bar{x}_{1}-\bar{x}_{2}}{\sqrt{\frac{\left(n_{1}-1\right) s_{1}{ }^{2}+\left(n_{2}-1\right) s_{2}{ }^{2}}{n_{1}+n_{2}-2}\left(\frac{1}{n_{1}}+\frac{1}{n_{2}}\right)}}$

dengan,

$\bar{x}_{1}$ : Nilai rata-rata sampel kelompok1

$\bar{x}_{2}$ : Nilai rata-rata sampel kelompok 2

$s_{1}^{2}$ : Varians sampel kelompok 1

$s_{2}{ }^{2}$ : Varians sampel kelompok 2

$n_{1}$ : Banyaknya anggota sampel kelompok 1

$n_{2}$ : Banyaknya anggota sampel kelompok 2

Kriteria pengujiannya adalah $\mathrm{H}_{0}$ ditolak jika nilai $t_{\text {hitung }}>$ nilai $t_{(0,05 ;(n 1+n 2-2))}$ atau nilai signifikansi kurang dari 0,05. Perhitungannya menggunakan bantuan SPSS 17 for windows.

Pengujian hipotesis univariat yang pertama, adalah sebagai berikut.

$\mathrm{H}_{0}: \mu_{1 p} \leq \mu_{2 p}$ dan $\mathrm{H}_{1}: \mu_{1 p}>\mu_{2 p}$ dengan,

$\mu_{1 p}$ : mean dari prestasi belajar dengan menggunakan model pembelajaran matematika realistik

$\mu_{2 p}$ : mean dari prestasi belajar dengan menggunakan model cooperative learning tipe STAD

Pengujian hipotesis univariat yang kedua, adalah sebagai berikut.

$\mathrm{H}_{0}: \mu_{1 p} \leq \mu_{0 p}$ dan $\mathrm{H}_{1}: \mu_{1 p}>\mu_{0 p}$ dengan,

$\mu_{1 p}$ : mean dari prestasi belajar dengan menggunakan model pembelajaran matematika realistik

$\mu_{0 p}$ : mean dari prestasi belajar dengan menggunakan model pembelajaran langsung

Pengujian hipotesis univariat yang ketiga, adalah sebagai berikut.

$\mathrm{H}_{0}: \mu_{2 p} \leq \mu_{0 p}$ dan $\mathrm{H}_{1}: \mu_{2 p}>\mu_{0 p}$ dengan,

$\mu_{2 p}$ : mean dari prestasi belajar dengan menggunakan model cooperative learning tipe STAD 
$\mu_{0 p}$ : mean dari prestasi belajar dengan menggunakan model pembelajaran langsung

Pengujian hipotesis univariat yang keempat, adalah sebagai berikut.

$\mathrm{H}_{0}: \mu_{1 k} \leq \mu_{2 k}$ dan $\mathrm{H}_{1}: \mu_{1 k}>\mu_{2 k}$ dengan,

$\mu_{1 k}$ : mean dari kreativitas siswa dengan menggunakan model pembelajaran matematika realistik

$\mu_{2 k}$ : mean dari kreativitas siswa dengan menggunakan model cooperative learning tipe STAD

Pengujian hipotesis univariat yang kelima, adalah sebagai berikut.

$\mathrm{H}_{0}: \mu_{1 k} \leq \mu_{0 k}$ dan $\mathrm{H}_{1}: \mu_{1 k}>\mu_{0 k}$ dengan,

$\mu_{1 k}$ : mean dari kreativitas siswa dengan meng-

gunakan model pembelajaran matematika realistik

Tabel 4. Perbandingan Statistik Deskriptif Prestasi Belajar dan Kreativitas Siswa pada Kelas Eksperimen dan Kelas Kontrol

\begin{tabular}{cccccc}
\hline \multirow{2}{*}{ Kelompok } & \multicolumn{2}{c}{ Prestasi Belajar } & \multicolumn{2}{c}{ Kreativitas Siswa } \\
& Awal & Akhir & Awal & Akhir \\
\hline \multirow{3}{*}{ Jumlah Responden } & KE2 & 28 & 28 & 28 & 28 \\
& KK & 26 & 26 & 26 & 26 \\
Skor Terendah & KE1 & 25 & 27 & 27 & 27 \\
& KE2 & 25 & 50 & 70 & 78 \\
Skor Tertinggi & KKK & 20 & 40 & 67 & 72 \\
& KE1 & 85 & 100 & 114 & 64 \\
Rata-rata & KE2 & 75 & 100 & 111 & 115 \\
& KK & 60 & 100 & 109 & 108 \\
& KE1 & 49,11 & 87,68 & 86,57 & 100,11 \\
& KE2 & 50,58 & 79,42 & 86,81 & 92,54 \\
& KK & 46,48 & 70,19 & 85,11 & 85,48 \\
& KE1 & 13,41 & 12,21 & 10,65 & 12,97 \\
& KE2 & 13,95 & 17,05 & 11,90 & 11,81 \\
& KK & 10,81 & 16,44 & 10,19 & 13,48 \\
& KE1 & 179,73 & 149,04 & 113,51 & 168,32 \\
& KE2 & 194,65 & 290,65 & 141,52 & 139,38 \\
& KK & 116,95 & 270,16 & 103,80 & 181,72 \\
\hline
\end{tabular}

Keterangan,

KE1 : Kelas eksperimen 1 yaitu kelas dengan model Pembelajaran Matematika Realistik

KE2: Kelas ekspereimen kedua dengan menggunakan model pembelajaran kooperatif tipe STAD

KK : Kelas kontrol yaitu kelas dengan model pembelajaran langsung $\mu_{0 k}$ : mean dari kreativitas siswa dengan menggunakan model pembelajaran langsung

Pengujian hipotesis univariat yang keenam, adalah sebagai berikut.

$\mathrm{H}_{0}: \mu_{2 k} \leq \mu_{0 k}$ dan $\mathrm{H}_{1}: \mu_{2 k}>\mu_{0 k}$ dengan,

$\mu_{2 k}$ : mean dari kreativitas siswa dengan menggunakan model cooperative learning tipe STAD

$\mu_{0 k}$ : mean dari kreativitas siswa dengan menggunakan model pembelajaran langsung

\section{Hasil Penelitian dan Pembahasan}

Hasil belajar berupa nilai prestasi dan skor kreativitas siswa pada ketiga kelompok, dipaparkan menggunakan statistik deskriptif pada tabel 4 berikut. 
Tabel 5. Perbandingan Ketuntasan Prestasi Belajar Siswa pada Kelas Eksperimen dan Kontrol

\begin{tabular}{|c|c|c|c|c|c|c|c|}
\hline \multicolumn{3}{|c|}{ Kelas } & Kategori & Nilai & Jumlah Siswa & Persentase $(\%)$ & Kategori \\
\hline \multirow{4}{*}{\multicolumn{2}{|c|}{$\begin{array}{l}\sum_{0} \\
\frac{0}{8} \\
\sum \\
\sum\end{array}$}} & \multirow{4}{*}{$\widehat{\vec{\Phi}}$} & \multirow{2}{*}{ Pretest } & $X>69,9$ & 2 & 7 & Tuntas \\
\hline & & & & $X \leq 69,9$ & 26 & 93 & Belum Tuntas \\
\hline & & & \multirow{2}{*}{ Postest } & $X>69,9$ & 26 & 93 & Tuntas \\
\hline & & & & $X \leq 69,9$ & 2 & 7 & Belum Tuntas \\
\hline \multirow{4}{*}{$\begin{array}{l}\overline{0} \\
\frac{0}{2} \\
\sum\end{array}$} & \multirow{4}{*}{ 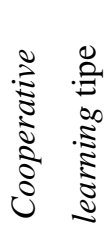 } & \multirow{4}{*}{ 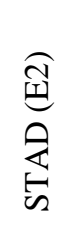 } & \multirow{2}{*}{ Pretest } & $X>69,9$ & 4 & 15 & Tuntas \\
\hline & & & & $X \leq 69,9$ & 22 & 85 & Belum Tuntas \\
\hline & & & \multirow{2}{*}{ Postest } & $X>69,9$ & 18 & 69 & Tuntas \\
\hline & & & & $X \leq 69,9$ & 8 & 31 & Belum Tuntas \\
\hline \multirow{4}{*}{$\begin{array}{l}\overline{0} \\
\bar{\delta} \\
\Sigma\end{array}$} & \multirow{4}{*}{ 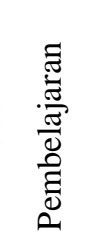 } & \multirow{4}{*}{ 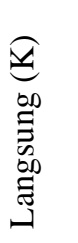 } & \multirow{2}{*}{ Pretest } & $X>69,9$ & 0 & 0 & Tuntas \\
\hline & & & & $X \leq 69,9$ & 27 & 100 & Belum Tuntas \\
\hline & & & \multirow{2}{*}{ Postest } & $X>69,9$ & 9 & 33 & Tuntas \\
\hline & & & & $X \leq 69,9$ & 14 & 67 & Belum Tuntas \\
\hline
\end{tabular}

Dari tabel tersebut terlihat bahwa ada peningkatan banyaknya siswa yang tuntas dari sebelum perlakuan ke setelah perlakuan pada kelas model Pembelajaran Matematika Realistik, kenaikan sebesar $86 \%$. Pada kelas model cooperative learning tipe STAD juga terlihat bahwa ada peningkatan banyaknya siswa yang tuntas dari sebelum perlakuan ke setelah perlakuan sebesar 54\%. Sedangkan pada kelas model pembelajaran langsung peningkatan banyaknya siswa yang tuntas dari sebelum perlakuan ke setelah perlakuan sebesar 33\%. Untuk memerkuat hasil, dilanjutkan uji hipotesis dengan uji $t$ satu sampel, dengan $\mathrm{H}_{0}: \mu \leq 69,9$ dan $\mathrm{H}_{1}: \mu>69,9$. Perhitungannya adalah sebagai berikut.

Tabel 6. Nilai Signifikasi One t Test Variabel

Prestasi pada Kelas Eksperimen dan Kontrol

\begin{tabular}{lcc}
\hline \multicolumn{1}{c}{ Kelas } & Nilai t & Nilai Signifikansi \\
\hline KE1 & 7,663 & 0,000 \\
KE2 & 2,818 & 0,009 \\
KK & 0,059 & 0,954 \\
\hline
\end{tabular}

Dari tabel 6 terlihat bahwa nilai $\mathrm{t}$ pada kelas model PMR adalah 7,663, dengan nilai signifikansi sebesar 0,000 , apabila dibandingkan dengan nilai $t$ tabel pada taraf signifikansi $5 \%$, maka nilai signifikansi kurang dari dari 0,05 , maka dapat disimpulkan $\mathrm{H}_{0}$ ditolak. Jadi dapat disimpulkan bahwa model Pembelajaran
Matematika Realistik efektif ditinjau dari aspek prestasi.

Berdasarkan Tabel 6, dalam kelas dengan model cooperative learning tipe STAD, terlihat bahwa nilai t adalah 2,818, dengan nilai signifikansi sebesar 0,009, apabila dibandingkan dengan taraf signifikansi 5\%, maka nilai signifikansi kurang dari dari 0,05 , maka dapat disimpulkan $\mathrm{H}_{0}$ diterima. Jadi dapat disimpulkan bahwa model Cooperative learning tipe STAD efektif ditinjau dari aspek prestasi.

Pada Tabel 6, untuk kelas model pembelajaran langsung, terlihat bahwa nilai $t$ adalah 0,059, dengan nilai signifikansi sebesar 0,954, apabila dibandingkan dengan taraf signifikansi $5 \%$, maka nilai signifikansi lebih dari dari 0,05 , maka dapat disimpulkan $\mathrm{H}_{0}$ diterima. Jadi dapat disimpulkan bahwa model pembelajaran langsung belum efektif ditinjau dari aspek prestasi. Ternyata meskipun ada peningkatan sebesar $33 \%$ dan rata-rata postes sebesar 70,19, hasil ini belum menunjukkan secara signifikan bahwa pembelajaran dengan model pembelajaran langsung efektif.

\section{Keefektifan Ditinjau Ddari Kreativitas Siswa}

Kriteria keefektifan pembelajaran dengan model Pembelajaran Matematika Realistik, model cooperative learning tipe STAD dan model pembelajaran langsung ditinjau dari kreativitas siswa yaitu ketika ada perbedaan yang signifikan antara kreativitas sebelum dan sesudah perlakuan. Sebelum melihat keefektifan dari model pembelajaran tersebut, terlebih 
dahulu ditunjukkan persentase kategori kreativitas siswa setelah proses pembelajaran baik pada kelas kontrol maupun pada kelas eksperimen. Kategori terdiri dari kreativitas sangat tinggi, tinggi, sedang, rendah dan sangat rendah. Kategorisasi kreativitas siswa ditentukan berdasar tabel berikut.

Tabel 7. Perbandingan Kategorisasi Kreativitas Siswa pada Kelas Eksperimen dan Kelas Kontrol

\begin{tabular}{|c|c|c|c|c|c|}
\hline & Kelas & Kategori & Jumlah Siswa & Persentase (\%) & Kategori Sikap Siswa \\
\hline \multirow{5}{*}{\multicolumn{2}{|c|}{ 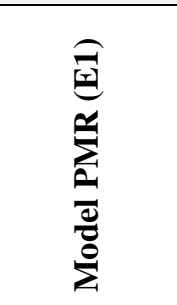 }} & $X \geq 117$ & 5 & 18 & Sangat tinggi \\
\hline & & $98 \leq X<117$ & 11 & 39 & Tinggi \\
\hline & & $78 \leq X<98$ & 11 & 39 & Cukup Tinggi \\
\hline & & $59 \leq X<78$ & 1 & 4 & Rendah \\
\hline & & $X<59$ & 0 & 0 & Sangat rendah \\
\hline \multirow{5}{*}{ 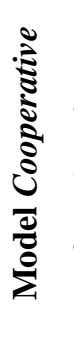 } & \multirow{5}{*}{ 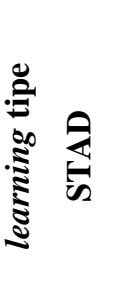 } & $X \geq 117$ & 0 & 0 & Sangat tinggi \\
\hline & & $98 \leq X<117$ & 9 & 35 & Tinggi \\
\hline & & $78 \leq X<98$ & 15 & 58 & Cukup Tinggi \\
\hline & & $59 \leq X<78$ & 2 & 8 & Rendah \\
\hline & & $X<59$ & 0 & 0 & Sangat rendah \\
\hline \multirow{5}{*}{$\frac{\bar{d}}{\mathrm{~d}}$} & \multirow{5}{*}{ 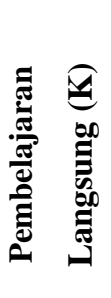 } & $X \geq 117$ & 0 & 0 & Sangat tinggi \\
\hline & & $98 \leq X<117$ & 7 & 26 & Tinggi \\
\hline & & $78 \leq X<98$ & 11 & 41 & Cukup Tinggi \\
\hline & & $59 \leq X<78$ & 9 & 33 & Rendah \\
\hline & & $X<59$ & 0 & 0 & Sangat rendah \\
\hline
\end{tabular}

Dari Tabel 7 terlihat bahwa pada kelas model PMR persentase siswa yang memiliki kreativitas sangat tinggi ada $18 \%$, tinggi ada sebanyak 39\%, cukup tinggi 39\% dan rendah hanya $4 \%$. Pada kelas model cooperative learning tipe STAD persentase siswa yang memiliki kreativitas tinggi ada sebanyak $35 \%$, cukup tinggi $58 \%$ dan rendah sebesar $8 \%$. Sedangkan pada kelas model pembelajaran langsung persentase siswa yang memiliki kreativitas tinggi ada sebanyak 26\%, cukup tinggi $41 \%$ dan rendah $33 \%$. Hal ini menunjukkan bahwa pada kelas model PMR terdapat $18 \%$ siswa dengan kreativitas sangat tinggi, sedangkan pada kelas model yang lain tidak ada. dilihat dari persentase kategori kreativitas terlihat bahwa untuk model PMR lebih baik dibandingkan dengan model cooperative learning tipe STAD dan model pembelajaran langsung. Untuk selanjutnya dilakukan uji paired sample $t$ test untuk menunjukkan bahwa model pembelajaran efektif atau tidak ditinjau dari kreativitas siswa. Hipotesis yang diuji adalah sebagai berikut.

$$
\begin{aligned}
& \mathrm{H}_{0}: \mu_{\text {postes }} \leq \mu_{\text {pretes }} \\
& \mathrm{H}_{1}: \mu_{\text {postes }}>\mu_{\text {pretes }}
\end{aligned}
$$

Perhitungannya adalah sebagai berikut.

Tabel 8. Nilai $t$ dan Nilai Signifikansi

Kreativitas dengan Paired $t$ Test pada Kelas

\begin{tabular}{|c|c|c|}
\hline Kelas & Nilai $t$ & Nilai Signifikansi \\
\hline KE1 & 4,516 & 0,000 \\
\hline KE2 & 2,331 & 0,028 \\
\hline KK & 0,155 & 0,878 \\
\hline
\end{tabular}
Eksperimen dan Kelas Kontrol

Dari Tabel 8 terlihat bahwa pada kelas model PMR, terlihat bahwa nilai t adalah 4,516, dengan nilai signifikansi sebesar 0,000, apabila dibandingkan dengan taraf signifikansi 5\%, maka nilai signifikansi kurang dari dari 0,05, maka dapat disimpulkan $\mathrm{H}_{0}$ ditolak. Jadi dapat disimpulkan bahwa model Pembelajaran Matematika Realistik efektif ditinjau dari aspek kreativitas siswa. 
Pada kelas model cooperative learning tipe STAD, terlihat bahwa nilai $\mathrm{t}$ adalah 2,331, dengan nilai signifikansi sebesar 0,028 , apabila dibandingkan dengan taraf signifikansi 5\%, maka nilai signifikansi kurang dari 0,05, maka dapat disimpulkan $\mathrm{H}_{0}$ ditolak. Jadi dapat disimpulkan bahwa model Cooperative learning tipe Student Team Achievement Division (STAD) efektif ditinjau dari aspek kreativitas siswa.

Selanjutnya pada kelas model pembelajaran langsung, terlihat bahwa nilai $\mathrm{t}$ adalah 0,155 , dengan nilai signifikansi sebesar 0,878 , apabila dibandingkan dengan taraf signifikansi $5 \%$, maka nilai signifikansi lebih dari 0,05 , maka dapat disimpulkan $\mathrm{H}_{0}$ diterima. Jadi dapat disimpulkan bahwa model Pembelajaran Langsung tidak efektif ditinjau dari aspek kreativitas siswa.

Perbandingan Keefektifan Model Pembelajaran

Hasil perhitungan dari uji kolmogorv smirnov dengan menggunakan SPSS 17 adalah sebagai berikut.

Tabel 9. Nilai Signifikansi Uji Kolmogorov Smirnov Data Akhir

\begin{tabular}{lc}
\hline \multicolumn{1}{c}{ Variabel } & Nilai Signifikansi \\
\hline Prestasi & 0,102 \\
Kreativitas & 0,508
\end{tabular}

Nilai signifikansi pada tabel terlihat bahwa untuk masing-masing variabel atau aspek nilainya lebih dari 0,05 . Jadi dapat disimpulkan bahwa nilai dan skor hasil pengukuran prestasi dan kreativitas siswa berdistribusi normal.

Uji homogenitas varians kovarians kedua populasi digunakan untuk mengetahui varians kovarians kedua populasi sama atau tidak. Box's $M$ test untuk menilai kesamaan matriks varians kovarians. Kriteria pengujian ditetapkan jika nilai peluang galat lebih dari taraf signifikansi, maka varians kedua populasi sama. Hasil perhitungan dengan menggunakan program SPSS 17 adalah sebagai berikut.
Tabel 10. Rangkuman Uji Homogenitas Data Akhir dengan Box's M test

\begin{tabular}{ccc}
\hline Nilai Box's $\boldsymbol{M}$ & Nilai $\mathbf{F}$ & Nilai Sig. \\
\hline 4,266 & 0,685 & 0,662 \\
\hline
\end{tabular}

Perhitungan selengkapnya ada pada lampiran 8b. Dari hasil perhitungan, terlihat bahwa nilai peluang galat lebih dari taraf signifikansi 5\% atau 0,05, maka dapat disimpulkan bahwa variansi kedua populasi adalah sama atau homogen.

Dari hasil analilis keefektifan telah diperoleh bahwa masing-masing model baik itu model Pembelajaran Matematika Realistik maupun Cooperative learning tipe STAD adalah efektif. Untuk menyimpulkan tentang keefektifan kedua buah model pembelajaran maka dilakukan uji hipotesis sebagai berikut.

$\mathrm{H}_{0}:\left(\begin{array}{l}\mu_{1 p} \\ \mu_{1 k}\end{array}\right)=\left(\begin{array}{l}\mu_{2 p} \\ \mu_{2 k}\end{array}\right)=\left(\begin{array}{l}\mu_{0 p} \\ \mu_{0 k}\end{array}\right)$

$\mathrm{H}_{1}$ : Tidak semua vektor rata-rata ketiga populasi sama

Tabel 11. Rangkuman Uji Multivariat Data Akhir dengan MANOVA pada Kelas Eksperimen dan Kelas Kontrol

\begin{tabular}{lcrr}
\hline \multicolumn{1}{c}{ Kategori } & Nilai & \multicolumn{1}{c}{ Nilai F } & Nilai Sig \\
\hline Pillai's Trace & 0,290 & 6,625 & 0,000 \\
Wilks' Lambda & 0,710 & 7,201 & 0,000 \\
Hotelling's Trace & 0,409 & 7,769 & 0,000 \\
Roy's Largest & 0,409 & 15,934 & 0,000 \\
Root & & & \\
\hline
\end{tabular}

Dari hasil perhitungan tersebut nilai peluang galat (Sig.) untuk Pillai's Trace, Wilks Lambda, Hotteling's Trace dan Roy's Largest Root pada Grup adalah kurang dari 0,05 maka $\mathrm{H}_{0}$ diterima. Jadi, dapat disimpulkan bahwa terdapat perbedaan keefektifan antara model Pembelajaran Matematika Realistik, model Cooperative learning tipe STAD, dan model pembelajaran langsung ditinjau dari prestasi belajar dan kreativitas siswa secara bersamasama.

Berdasarkan hasil uji hipotesis multivariat dengan diperoleh kesimpulan terdapat perbedaan keefektifan antara model Pembelajaran Matematika Realistik, model Cooprative Learning tipe STAD, dan model pembelajaran langsung ditinjau dari prestasi belajar dan kreativitas siswa secara bersama-sama. Oleh karena itu, selanjutnya dilakukan uji hipotesis univariat 
untuk menentukan manakah yang lebih efektif ditinjau dari masing-masing aspek, yaitu prestasi belajar dan kreativitas siswa.

Sebelum uji hipotesis dilakukan, terlebih dahulu dilakukan uji homegenitas variansi untuk kedua populasi dari masing masing aspek. Uji homogenitas yang dilakukan adalah dengan uji Levene. Dengan menggunakan SPSS 17 diperoleh hasil sebagai berikut.

Tabel 12. Uji Homogenitas dengan Levene's Test

\begin{tabular}{ccc}
\hline Variabel & Nilai F & Nilai Signifikansi \\
\hline Prestasi & 2,534 & 0,101 \\
Kreativitas & 0,680 & 0,510
\end{tabular}

Berdasarkan tabel di atas, diperoleh nilai peluang galat untuk masing-masing variabel adalah lebih dari 0,05 , hal ini menunjukkan bahwa variansi kedua populasi adalah homogen.

Untuk melihat model pembelajaran mana yang lebih efektif maka digunakan uji t.

Tabel 13. Nilai t dan Signifikasi Independent Samples $t$ Test kelas PMR dan STAD

\begin{tabular}{ccc}
\hline Variabel & Nilai t & Nilai Signifikansi \\
\hline Prestasi & 2,037 & 0,045
\end{tabular}

Dari hasil perhitungan diperoleh nilai $\mathrm{t}_{\text {hitung }}=2,037>1,675$ atau peluang galatnya adalah 0,02 yaitu kurang dari 0,05 sehingga $\mathrm{H}_{0}$ ditolak, maka dapat disimpulkan Model Pembelajarn Matematika Realistik lebih efektif daripada model Coopreative Learning tipe STAD ditinjau dari aspek prestasi.

Tabel 14. Nilai t dan Signifikasi Independent Samples $t$ Test kelas PMR dan Langsung

\begin{tabular}{lcc}
\hline \multicolumn{1}{c}{ Variabel } & Nilai t & Nilai Signifikansi \\
\hline Prestasi & 4,492 & 0,000 \\
\hline
\end{tabular}

Dari hasil perhitungan diperoleh nilai $\mathrm{t}_{\text {hitung }}=4,492>1,674$ atau peluang galatnya adalah 0,000 yaitu kurang dari 0,05 sehingga $\mathrm{H}_{0}$ ditolak, maka dapat disimpulkan Model Pembelajaran Matematika Realistik lebih efektif daripada model Pembelajaran Langsung ditinjau dari aspek prestasi.
Tabel 15. Nilai t dan Signifikasi Independent Samples $t$ Test kelas STAD dan Langsung

\begin{tabular}{lcc}
\hline \multicolumn{1}{c}{ Variabel } & Nilai t & Nilai Signifikansi \\
\hline Prestasi & 2,008 & 0,050 \\
\hline
\end{tabular}

Perhitungan selengkapnya ada pada lampiran 9d. Dari hasil perhitungan diperoleh nilai $t_{\text {hitung }}=2,008>1,675$ sehingga $\mathrm{H}_{0}$ ditolak, maka dapat disimpulkan Model Pembelajarn Coopreative Learning tipe STAD lebih efektif dibandingkan model Pembelajaran Langsung ditinjau dari aspek prestasi.

Uji t Aspek Kreativitas Siswa

Untuk melihat model pembelajaran mana yang lebih efektif ditinjau dari aspek kreativitas siswa maka digunakan uji t.

Model Pembelajaran Matematika Realistik dengan Model Cooperative Learning tipe STAD

Hipotesis yang digunakan adalah sebagai berikut.

$$
\begin{aligned}
& \mathrm{H}_{0}: \mu_{1 k} \leq \mu_{2 k} \\
& \mathrm{H}_{1}: \mu_{1 k}>\mu_{2 k}
\end{aligned}
$$

Kriteria penolakan $\mathrm{H}_{0}$ adalah ketika nilai $t_{\text {hitung }}>$ nilai $t_{(0,05 ; 52)}=1,675$ nilai peluang galat kurang dari taraf signifikansi 0,05, maka $\mathrm{H}_{0}$ ditolak.hasil perhitungan dengan menggunakan SPSS 17 adalah sebagai berikut.

Tabel 16. Nilai t dan Signifikasi Independent Samples $t$ Test kelas PMR dan STAD

\begin{tabular}{ccc}
\hline Variabel & Nilai t & Nilai Signifikansi \\
\hline Kreativitas & 2,236 & 0,030 \\
\hline
\end{tabular}

Dari hasil perhitungan diperoleh $t_{\text {hitung }}=$ 2,236>1,675 atau peluang galatnya adalah 0,03 yaitu kurang dari 0,05 , sehingga $\mathrm{H}_{0}$ ditolak, maka dapat disimpulkan Model Pembelajaran Matematika Realistik lebih efektif daripada model Coopreative Learning tipe STAD ditinjau dari aspek kreativitas siswa.

Tabel 17. Nilai t dan Signifikasi Independent Samples $t$ Test Kelas PMR dan Langsung

\begin{tabular}{ccc}
\hline Variabel & Nilai t & Nilai Signifikansi \\
\hline Prestasi & 4,100 & 0,000 \\
\hline
\end{tabular}


Dari hasil perhitungan diperoleh nilai $t_{\text {hitung }}=4,100>1,674$ atau peluang galatnya adalah 0,000 yaitu kurang dari 0,05 sehingga $\mathrm{H}_{0}$ ditolak, maka dapat disimpulkan Model Pembelajaran Matematika Realistik lebih efektif dari-pada model Pembelajaran Langsung ditinjau dari aspek kreativitas siswa.

Tabel 18. Nilai t dan Signifikasi Independent Samples $t$ Test kelas STAD dan Langsung

\begin{tabular}{ccc}
\hline Variabel & Nilai t & Nilai Signifikansi \\
\hline Prestasi & 2,024 & 0,048
\end{tabular}

Dari hasil perhitungan diperoleh nilai $\mathrm{t}_{\text {hitung }}=2,024>1,675$ atau peluang galatnya adalah 0,048 yaitu kurang dari 0,05 sehingga $\mathrm{H}_{0}$ ditolak, maka dapat disimpulkan Model Pembelajaran Coopreative Learning tipe STAD lebih efektif dibandingkan model Pembelajaran Langsung ditinjau dari aspek kreativitas siswa.

Hasil uji MANOVA menunjukkan bahwa terdapat perbedaan yang signifikan antara keefektifan pembelajaran matematika dengan model Pembelajaran Matematika Realistik, model Cooperative learning tipe Student Team Achievement Division, dan model Pembelajaran Langsung ditinjau dari prestasi dan kreativitas siswa. Perbedaan ini memungkinkan untuk melanjutkan pengujian dengan uji $t$, untuk melihat aspek manakah yang berkontribusi terhadap perbedaan secara keseluruhan. Hasil dari uji t menunjukkan bahwa model Pembelajaran Matematika Realistik lebih efektif daripada kedua model yang lain ditinjau dari prestasi dan kreativitas siswa.

\section{Keefektifan Model Pembelajaran}

Dalam model pembelajaran dengan menggunakan model pembelajaran matematika realistik, siswa dilatih untuk menemukan sendiri dan menemukan kembali rumus-rumus matematika dengan bimbingan guru. Dalam pembelajaran matematika dengan menggunakan model pembelajaran matematika realistik siswa juga dituntut aktif dan mengungkapakan pendapat-pendapatnya serta tidak takut mencoba hal-hal yang baru. Dengan adanya pembelajaran tersebut maka dapat membangun kreativitas siswa yang tampak dari kelancaran berpikir, keluwesan, elaborasi dan orisinalitas.

Dalam pembelajaran kooperatif STAD siswa dibagi menjadi beberapa kelompok yang terdari dari 4-5 orang dengan anggota kelompok yang heterogen, siswa berdiskusi untuk memecahkan permasalahan yang diberikan, dalam interaksi ini siswa bisa belajar mengemukakan pendapat, mendengar pendapat orang lain bahkan menentang pendapat orang lain untuk memertahankan pendapatnya, hasil diskusi dipertanggungjawabkan oleh semua anggota kelompok karena skor keberhasilan tergantung dari skor kelompok, dan setelah itu diberikan kuis individu untuk mengecek pemahaman setiap siswa terhadap materi yang dipelajari.

Dalam pembelajaran langsung siswa belajar secara individu. Pembelajaran agak didominasi oleh guru, siswa menerima apa yang dijelaskan oleh guru. Dalam pemecahan suatu masalah atau soal siswa diminta mengungkapkan pendapat dan siswa lain diminta menanggapinya.

Berdasarkan uji multivariat dengan MANOVA menunjukkan bahwa terdapat perbedaan yang signifikan antara keefektifan pembelajaran matematika dengan model pembelajaran matematika realistik, Cooperative Learning tipe Student Team Achievement Division, dan pembelajaran langsung ditinjau dari prestasi siswa, sikap siswa dan motivasi siswa. Perbedaan ini mungkin saja terjadi, walaupun ketiga model pembelajaran memang sama-sama efektif. Ketiga model pembelajaran tersebut sama-sama melibatkan diskusi, namun dalam pembelajaran matematika realistik pembelajaran dimulai dari hal yang konkret yang dekat dengan siswa baru kemudian ke abstrak sehingga memungkinkan siswa lebih memahami apa yang sedang mereka pelajari. Selain itu adanya matematika informal sebelum mereka menemukan rumus secara formal memungkinkan siswa mengembangkan gagasan dan mengungkapkan pendapat, sehingga lebih menggali kreativitas siswa.

\section{Perbandingan Keefektifan Model Pembelajaran}

Pembelajaran matematika dengan model Pembelajaran Matematika Realistik lebih efektif dibandingkan dengan model cooperative learning tipe STAD dan pembelajaran langsung ditinjau dari prestasi siswa. Berdasarkan hasil uji $\mathrm{t}$, diperoleh kesimpulan bahwa model Pembelajaran Matematika Realistik lebih efektif dibandingkan dengan model cooperative learning tipe STAD, dan model Pembelajaran Matematika Realistik lebih efektif dibandingkan dengan mode pembelajaran langsung. Dalam model pembelajaran matematika realistik, model pembelajarannnya berangkat dari sesuatu 
yang konkret baru kemudian ke abstrak. Dalam pemerolehan informasi siswa bekerja secara kelompok dan ada diskusi untuk mengungkapkan pendapat dan saling bertukar informasi. Dengan adanya proses belajar yang bertahap dan kerja sama dalam kelompok ternyata membantu siswa untuk lebih memahami apa yang sedang dipelajari.

Dalam model pembelajaran langsung, guru lebih dominan. Guru lebih ke menjelaskan dan memberikan rumus yang sudah jadi. Dalam pembelajaran ini siswa diminta untuk mendengarkan dan kemudian mengaplikasikan ke soal-soal seperti apa yang dicontohkan guru. Pembelajaran seperti ini membuat siswa dalam belajar hanya menunggu. Dalam pemahaman materi pun, belum tentu semua siswa memahami secara bermakna, bahkan kebanyakan melalui menghafal rumus.

Dari uraian di atas, terlihat bahwa model pembelajaran realistik lebih efektif daripada model pembelajaran langsung ditinjau dari prestasi belajar. Model pembelajaran realistik mampu menanamkan permasalahan atau materi secara bermakna dibandingkan dengan model pembelajaran langsung. Ketika di dalam pembelajaran matematika relaistik pemahaman siswa secara bertahap dan siswa mengalami sendiri, namun di dalam model pembelajaran langsung siswa cenderung pasif dan hanya mendengarkan kemudian mengaplikasikan.

Pembelajaran matematika dengan model cooperative learning tipe STAD lebih efektif dibandingkan dengan model pembelajaran langsung ditinjau dari prestasi belajar siswa siswa. Berdasarkan hasil uji-t, diperoleh bahwa model model cooperative learning tipe STAD lebih efektif dibandingkan dengan model pembel-ajaran langsung ditinjau dari prestasi siswa. Hal ini dikaitkan pula dengan skor pretest dan post-test yang mengikuti model cooperative learning tipe STAD dan model pembelajaran langsung.

Dalam pembelajaran matematika realistik, pembelajaran dimulai dengan masalahmasalah realistik yang memungkinkan bisa diselesaikan dengan beragam prosedur penyelesaian. Siswa diberi kesempatan untuk menyelesaikan masalah berdasarkan pengetahuan informalnya atau gagasannya sendiri sehingga siswa bisa mengkonstruksi pengetahuan mereka berdasarkan pengetahuan sebelumnya yang kemudian dengan bantuan dan bimbingan guru atau teman berusaha untuk menemukan konsep dan prinsip matematika.
Dalam model Cooperative learning tipe Student Team Achievement Division (STAD), peserta didik pun mampu belajar optimal. Hal ini dikarenakan model cooperative learning tipe STAD dirancang untuk mengatasi kesulitan belajar siswa secara individual. Oleh karena itu kegiatan pembelajarannya lebih banyak digunakan untuk pemecahan masalah, ciri khas pada tipe STAD ini adalah setiap siswa belajar secara berkelompok dan memunyai tanggung jawab pada setiap anggota kelompok agar bisa memahami permasalahan. Adanya kuis secara individual yang menyumbang kesuksesan kelompok, menuntut adanya kerja sama yang tinggi dalam kelompok agar semua siswa dalam kelompok bisa mengerjakan kuis secara individual.

Dalam model pembelajaran langsung, guru lebih dominan. Guru lebih ke menjelaskan dan memberikan rumus yang sudah jadi. Dalam pembelajaran ini siswa diminta untuk mendengarkan dan kemudian mengaplikasikan ke soal-soal seperti apa yang dicontohkan guru. Pembelajaran seperti ini membuat siswa dalam belajar hanya menunggu. Dalam pemahaman materi pun, belum tentu semua siswa memahami secara bermakna, bahkan kebanyakan melalui menghafal rumus.

Dari uraian di atas, terlihat bahwa memang model cooperative learning tipe STAD mampu membuat siswa belajar optimal. Dengan adanya tahap-tahap pada model STAD, ternyata model ini lebih efektif dari pembelajaran langsung dilihat dari prestasi siswa.

Pembelajaran matematika dengan model Pembelajaran Matematika Relaistik lebih efektif dibandingkan dengan model Cooperative learning tipe STAD dan model pembelajaran langsung ditinjau dari kreativitas siswa. Berdasarkan hasil uji t, diperoleh bahwa model pembelajaan matematika realistik lebih efektif dari model Cooperative learning tipe STAD dan model pembelajaran langsung ditinjau dari kreativitas siswa. Skor kreativitas siswa yang mengikuti model pembelajaan matematika realistik, dan model Cooperative learning tipe STAD dan model pembelajaran langsung dikaitkan dengan banyaknya siswa yang memunyai kreativitas tinggi ternyata menunjukkan bahwa model pembelajaan matematika realistik lebih efektif dari model Cooperative learning tipe STAD dan model pembelajaran langsung.

Dalam model pembelajaran dengan menggunakan model pembelajaran matematika realistik, siswa dilatih untuk menemukan sen- 
diri dan menemukan kembali rumus-rumus matematika dengan bimbingan guru. Dalam pembelajaran matematika dengna menggunakan model pembelajaran matematika realistik siswa juga dituntut aktif dan mengungkapakan pendapat-pendapatnya serta tidak takut mencoba hal-hal yang baru. Dengan adanya pembelajaran tersebut maka dapat membangun kreativitas siswa yang tampak dari kelancaran berpikir, keluwesan, elaborasi dan orisinalitas.

Dalam model Cooperative learning tipe STAD setiap siswa bekerja secara kelompok yang terdiri dari 4-5 siswa. Setelah itu adanya diskusi kelas yang berupa menyampaikan pendapat di depan kelas, serta adanya tanggapan dari siswa lain mampu membangun kreativitas siswa yang tampak dari kelancaran berpikir.

Dalam model pembelajaran langsung, guru lebih dominan. Guru lebih ke menjelaskan dan memberikan rumus yang sudah jadi. Dalam pembelajaran ini siswa diminta untuk mendengarkan dan kemudian mengaplikasikan ke soal-soal seperti apa yang dicontohkan guru. Pembelajaran seperti ini membuat siswa dalam belajar hanya menunggu. Dalam pemahaman materi pun, belum tentu semua siswa memahami secara bermakna, bahkan kebanyakan melalui menghafal rumus. Hal ini kurang membangun kreativitas siswa baik dari segi dari kelancaran berpikir, keluwesan, elaborasi dan orisinalitas.

Dari uraian di atas terlihat bahwa baik dalam model pembelajaran matematika realistik mampu membangun membangun kreativitas siswa. Dengan adanya diskusi pada kelompok dan siswa beruasaha menemukan rumus atau memecahkan masalah dengan menggunakan caranya sendiri, ternyata membuat model ini lebih efektif daripada kedua model yang lain.

Pembelajaran matematika dengan model Cooperative learning tipe Student Team Achievement Division lebih efektif dibandingkan dengan model pembelajaran langsung ditinjau dari kreativitas siswa.

Dalam model Cooperative learning tipe STAD setiap siswa bekerja secara kelompok yang terdiri dari 4-5 siswa. Setelah itu adanya diskusi kelas yang berupa menyampaikan pendapat di depan kelas, serta adanya tanggapan dari siswa lain mampu membangun kreativitas siswa yang tampak dari kelancaran berpikir.

Dalam model pembelajaran langsung, guru lebih dominan. Guru lebih ke menjelaskan dan memberikan rumus yang sudah jadi. Dalam pembelajaran ini siswa diminta untuk men- dengarkan dan kemudian mengaplikasikan ke soal-soal seperti apa yang dicontohkan guru. Pembelajaran seperti ini membuat siswa dalam belajar hanya menunggu. Dalam pemahaman materi pun, belum tentu semua siswa memahami secara bermakna, bahkan kebanyakan melalui menghafal rumus. Hal ini kurang membangun kreativitas siswa baik dari segi dari kelancaran berpikir, keluwesan, elaborasi dan orisinalitas.

Dari uraian di atas terlihat bahwa baik dalam model pembelajaran cooperative learning tipe STAD mampu membangun membangun kreativitas siswa daripada model pembelajaran langsung. Hal ini terlihat dengan adanya diskusi pada kelompok, pemecahan masalah, dan diskusi kelas.

\section{Simpulan dan Saran}

Simpulan

Berdasarkan analisis data dan pembahasan, maka dapat disimpulkan beberapa hal, di antaranya sebagai berikut: (1) Model pembelajaran matematika realistik efektif ditinjau dari prestasi belajar dan kreativitas siswa. (2) Model cooperative learning tipe Student Team Achievement Divison (STAD) efektif ditinjau dari prestasi belajar dan kreativitas siswa. (3) Terdapat perbedaan kefektifan antara model pembelajaran matematika realistik dengan model cooperative learning tipe STAD ditinjau dari prestasi belajar dan kreativitas siswa. (4) Model pembelajaran matematika realistik lebih efektif daripada model cooperative learning tipe STAD ditinjau dari prestasi belajar siswa. (5) Model pembelajaran matematika realistik lebih efektif daripada model cooperative learning tipe STAD ditinjau dari kreativitas siswa.

\section{Saran}

Berdasarkan hasil serta temuan penelitian, dan dengan memerhatikan keterbatasan penelitian, saran yang dapat disampaikan adalah sebagai berikut: (1) model Pembelajaran Matematika Realistik dan model cooperative learning tipe STAD efektif oleh karena itu disarankan untuk menerapkannnya pada proses pembelajaran matematika. (2) Model Pembelajaran Matematiatika Realistik lebih efektif dibandingkan model cooperative learning tipe STAD, oleh karena ituu disarankan untuk menerapkan model Pembelajaran Matematika Realistik agar pembelajaran lebih optimal. (3) Dalam mene- 
rapkan model pembelajaran matematika realistik, hendaknya siswa lebih dimotivasi agar mau mengungkapkan pendapatnya dan membiarkan siswa untuk menemukan sendiri suatu rumus atau algoritma dimana guru berperan sebagai fasilitator.

\section{Daftar Pustaka}

Ansor, M. (2009). Menumbuhkembangkan kreativitas siswa. Diambil pada tanggal 25 November 2009, dari http://www.alfalahsby.com/node/311

Hadi, Sutarto. (2005). Pendekatan matematika realistik dan implementasinya. Cetakan pertama, Tulip: Banjarmasin

Hasil UASBN sekolah swasta libas negeri. (2010, 11 Juni). KR Jogja. Diambil pada tanggal 8 Agustus 2010, dari http://www.krjogja.com/news/detail/36 504/Hasil.UASBN.SD..Sekolah.Swasta .Libas.Negeri.html
Marpaung, Y. (2008). Mengembangkan kemandirian siswa belajar matematika $\mathrm{Me}$ lalui PMRI. Makalah disampaikan pada Seminar Internasional Pendidikan Matematika Universitas Sanata Dharma Yogyakarta 29-30 April 2008

Ternyata pembelajaran matematika masih konvensional. (2009, 18 Juni). Kompas. Diambil pada tanggal 25 November 2009, dari http://edukasi.kompas.com/read/xml/20 09/06/18/20170782/ternyata.pembelajar an.matematika.masih.konvensional

Munandar, Utami. (2009). Pengembangan kreativitas anak berbakat. Jakarta: Rineka Cipta

Wong, H. K. (2013). There is only one way to improve student achievement. Diambil pada 19 Juli 2013 dari: http://www.newteacher.com/pdf/only1 way.pdf 